\title{
Human Ovarian Tumors of Epithelial Origin Express PDGF In Vitro and In Vivo
}

\author{
Marjan A. Versnel, Melang Haarbrink, Anthonie W. Langerak, \\ Petronella A. J. M. de Laat, Anne Hagemeijer, Theo H. van der Kwast, \\ Lia A. M. van den Berg-Bakker, and Poter I. Schrier
}

\begin{abstract}
In human malignant mesothelioma cell lines an elevation of the expression of the genes for the PDGF A-chain, PDGF B-chain, and PDGF $\beta$-receptor was found compared to normal mesothelial cells. As ovarian epithelial tumors originate from the ovarian surface epithelium, which is of mesothelial origin, we investigated PDGF chain and PDGF receptor mRNA expression in six human ovarian cell lines of epithelial origin and a granulosa tumor cell line. All six investigated ovarian epithelial tumor cell lines expressed the PDGF A-and B-chain genes, while the granulosa tumor cell line expressed the PDGF A-chain gene only. Expression of PDGF receptors was not found in the epithelial or granulosa tumor cell lines. Cytogenetic and molecular biological studies did not provide evidence for rearrangement or genomic amplification of the PDGF B-chain. Expression of PDGF was also demonstrated in ovarian tumors in vivo. Frozen sections of six serous ovarian carcinomas stained positive with an antibody against PDGF and negative with antibodies against the PDGF $\alpha$ - and $\beta$-receptors. These results suggest that PDGF expression might be a useful marker for ovarian carcinomas.
\end{abstract}

\section{INTRODUCTION}

In Western countries, cancer of the ovary is the fourth leading cause for cancer mortality in women. The number of deaths caused by ovarian cancer has surpassed the number caused by uterine cancer [1]. Ovarian cancers are a heterogeneous group of malignancies both with respect to histology and biological behavior. The common 'epithelial' tumors account for about two-thirds of all ovarian tumors and their malignant forms account for over $85 \%$ of all malignant ovarian tumors [2]. Histologically, ovarian epithelial tumors can be divided into serous, mucinous, endometrioid, clear-cell, and Brenner types. Apart from clinical staging and histological classification of ovarian tumors, the prognostic importance of histological grading has been demonstrated [3]. The so-called common epithelial tumors of the ovary originate from the surface epithelium, in the past erroneously called 'germinal epithelium'. Actually this epithelium is of mesothelial origin and constitutes the embryonal coelomic epithelium from which the Mullerian duct is derived $[4,5]$.

From the Departments of Immunology (M. A. V., M. H., A. W. L., P. A. J. M. de L.), Cell Biology and Genetics (A. H.), and Pathology (T. H. van der K.), Erasmus University, Rotterdam; and the Department of Clinical Oncology (L. A. M. van den B.B., P. I. S.), University Hospital, Leiden, The Netherlands.

Address reprint requests to: Dr. M. A. Versnel, Department of Immunology, Erasmus University, P.O. Box 1738, 3000 DR Rotterdam, The Netherlands.

Received June 22, 1993; accepted August 19, 1993.
Characterization of ovarian surface epithelial cells in vitro revealed a great resemblance to cultured normal mesothelial cells. Both cell types grow in vitro in pavement monolayers, have microvilli, and are keratin positive [6]. Most ovarian surface epithelial cells exhibited $17 \beta$-hydroxysteroid dehydrogenase activity, which was absent in cultured mesothelial cells. In vivo ovarian surface epithelial cells can be considered a specialized mesothelium that has the same properties as mesothelial cells but has a cyclic secretory and transport function as well [7]. The similarity in embryologic and histologic features of epithelial ovarian carcinomas with mesotheliomas has led to the proposition that all epithelial ovarian tumors are mesotheliomas [2].

In vitro normal and malignant human mesothelial cells have a remarkable pattern of PDGF chain and receptor expression. Cultured normal mesothelial cells were found to express PDGF A-chain mRNA and no PDGF B-chain mRNA. Human malignant mesothelial cells or mesothelioma cells were found to have an elevated PDGF A- and B-chain expression in vitro $[8,9]$. Furthermore, the malignant mesothelioma cell lines were found to express the PDGF $\beta$-receptor while no PDGF $\alpha$-receptors were detectable by Northern blot analysis [10]. These results are suggestive for autocrine stimulation of growth in cultured normal mesothelial cells (PDGFAA via the $\alpha$-receptor) and in malignant mesothelioma cell lines (PDGF-BB acting via the $\beta$-receptor).

As ovarian epithelial tumors are of mesothelial origin, we investigated the expression of PDGF chains and receptors in human ovarian epithelial tumor cell lines. The observed pat-
60

Cancer Genet Cytogenet 73:60-64 (1994)

$0165-4608 / 94 / \$ 07.00$ (c) 1994 Elsevier Science Inc.

655 Avenue of the Americas, New York, NY 10010 
tern was compared with normal and malignant mesothelial cells and an ovarian tumor cell line derived from a granulosa cell tumor, which is of ovarian stromal origin. Furthermore, the expression of PDGF and its receptors was also studied in frozen tissue sections of human ovarian tumors.

\section{MATERLALS AND METHODS}

\section{Cell Lines, Growth Conditions, and Cytogenetics}

Six human ovarian carcinoma cell lines of epithelial origin were used: COV413B, COV362.4, COV504, COV446B, COV644, and COV318 [11]. COV434 is derived from a granulosa cell tumor [11]. The isolation and growth conditions of these cell lines was described recently [11]. In Table 1 the origin of the tumor cell lines is listed. The malignant mesothelioma cell lines and normal mesothelial cell cultures were isolated and cultured as described [12]. Cytogenetic analysis was performed as described [9].

\section{Southern and Northern Blot Analysis}

DNA isolation and Southern blot analysis were performed as described earlier [9]. RNA isolation and Northern blot analysis were performed as described [9]. The PDGF A-chain probe was a 1.3-kb EcoRI fragment and the PDGF B-chain probe was a 1.7-kb BamHI c-sis fragment [13, 14]. The PDGF a-receptor probe was a 1.5-kb EcoRI fragment [15] and the PDGF $\beta$-receptor probe was a 1-kb PstI fragment [16]; both probes correspond to extracellular parts of the receptors. The GAPDH probe was a 0.7-kb EcoRI-PstI fragment [17]. The filters were washed at $42^{\circ} \mathrm{C}$ to $0.3 \times \mathrm{SSC}$ and exposed to Fuji-RX film.

\section{Immunohistochemistry}

Frozen sections $(5 \mu \mathrm{m})$ of tumor tissue of six ovarian carcinoma patients were fixed for 10 seconds in acetone at room temperature (RT) and stained by an indirect immunoperoxidase technique. Sections were pretreated for 15 minutes in PBS with $0.05 \%$ (v/v) Tween-20 (PBT) [18] and subsequently incubated with the primary antibody for 1 hour at RT. After rinsing with PBT the sections were incubated for 1 hour at
RT with the conjugate solution containing $10 \%$ (v/v) pooled human serum. After rinsing, the enzyme activity was visualized by incubation with diaminobenzidine (Sigma Chemical Co., St. Louis, MO) $(1 \mathrm{mg} / \mathrm{ml}$ PBS supplemented with $20 \mu \mathrm{l} 1 \%(\mathrm{v} / \mathrm{v}) \mathrm{H}_{2} \mathrm{O}_{2}$ ) at $\mathrm{RT}$ for 3 minutes. After dehydration the sections were embedded in Depex (B.D.H. Laboratory supplies, Poole, U.K.) and coverslipped. Nuclear counterstaining with hematoxylin was performed.

\section{Antibodies}

PDGF expression was detected using the mouse monoclonal antibody PGF007 ([19], Mochida Pharmaceutical, Tokyo, Japan). PDGF $\alpha$ - and $\beta$-receptors were recognized using mouse monoclonal antibodies against each type of receptor (Genzyme, Cambridge, MA). The ovarian carcinoma marker OV632 was kindly supplied by Dr. G. J. Fleuren [20]. As a negative control anti-mouse, IgG1 antibody was used (Becton Dickinson, San Jose, CA). As a control marker CD68 was used (Ki-M7, Behring, Marburg, Germany). A peroxidaseconjugated goat-anti-mouse-Ig-antibody (Dako, Glostrup, Denmark) was used as a second step.

\section{RESULTS}

\section{Expression of mRNA for the PDGF Chains and PDGF Receptors in Ovarian Tumor Cell Lines}

Total RNA was isolated from seven human ovarian tumor cell lines. The malignant mesothelioma cell line Mero-48b was used as a positive control for PDGF A- and B-chain expression. Cultured normal mesothelial cells were used as a negative control for PDGF B-chain expression [9]. All seven ovarian tumor cell lines showed expression of the 2.8-, 2.3-, and 1.9-kb PDGF A-chain specific transcripts (Fig. 1). COV413B and COV362.4, two cell lines of epithelial origin, had a weak PDGF A-chain expression, while the other investigated cell lines clearly showed the same level of PDGF A-chain expression as normal and malignant mesothelial cell lines.

Rehybridization of the same filter with a PDGF B-chain probe showed a variable expression of the 4.0-kb mRNA in

Table 1 Origin of the human ovarian tumor cell lines and summary of data on PDGF chain and receptor mRNA expression and cytogenetics concerning chromosome 22 in these cell lines

\begin{tabular}{|c|c|c|c|c|c|c|c|c|}
\hline \multirow[b]{2}{*}{ Cell line } & \multirow{2}{*}{$\begin{array}{l}\text { Histology of primary } \\
\text { tumor }\end{array}$} & \multicolumn{2}{|c|}{ PDGF } & \multicolumn{2}{|c|}{$\begin{array}{l}\text { PDGF } \\
\text { receptor }\end{array}$} & \multirow{2}{*}{$\begin{array}{l}\text { Modal chromosome } \\
\text { number (range) }\end{array}$} & \multirow{2}{*}{$\begin{array}{l}\text { Normal } \\
\text { chromosome } 22\end{array}$} & \multirow{2}{*}{$\begin{array}{l}\text { Rearranged } \\
\text { chromosome } 22\end{array}$} \\
\hline & & A-chain & B-chain & $a$ & $\beta$ & & & \\
\hline COV413B & Serous carcinoma & \pm & + & - & - & $38(36-42)$ & $\mathbf{0}$ & Marker \\
\hline COV362.4 & Endometrioid & \pm & \pm & - & - & $69(67-73)$ & 2 & 0 \\
\hline COV504 & Serous carcinoma & + & ++ & - & - & $64(62-66)$ & 2 & 0 \\
\hline COV446B & Serous carcinoma & + & ++ & - & - & $49(45-97)^{a}$ & 0 & $\begin{array}{l}\operatorname{der}(13) t(13 ; 22)(p 11 ; q 11) \\
\quad \operatorname{inv}(13 p+] \times 2\end{array}$ \\
\hline COV644 & Mucinous carcinoma & + & + & - & - & $58(50-60)$ & 3 & o \\
\hline COV318 & Serous carcinoma & + & ++ & - & - & $74(68-77)$ & 1 & $\begin{array}{l}\mathrm{t}(\mathrm{X} ; 22)(\mathrm{p} 11 ; \mathrm{q} 11) \times 2 ? \\
\quad \operatorname{der}(12) \mathrm{t}(12 ; 22)(\mathrm{p} 13 ; \mathrm{q} 11)\end{array}$ \\
\hline COV434 & Granulosa cell & + & - & - & - & $47(46-47)$ & 1 & $22 q+$ \\
\hline Mesothelial & & + & - & + & - & & & \\
\hline Mesothelioma & & ++ & ++ & - & + & & & \\
\hline
\end{tabular}

a $20 \%$ of cells were tetraploid. 

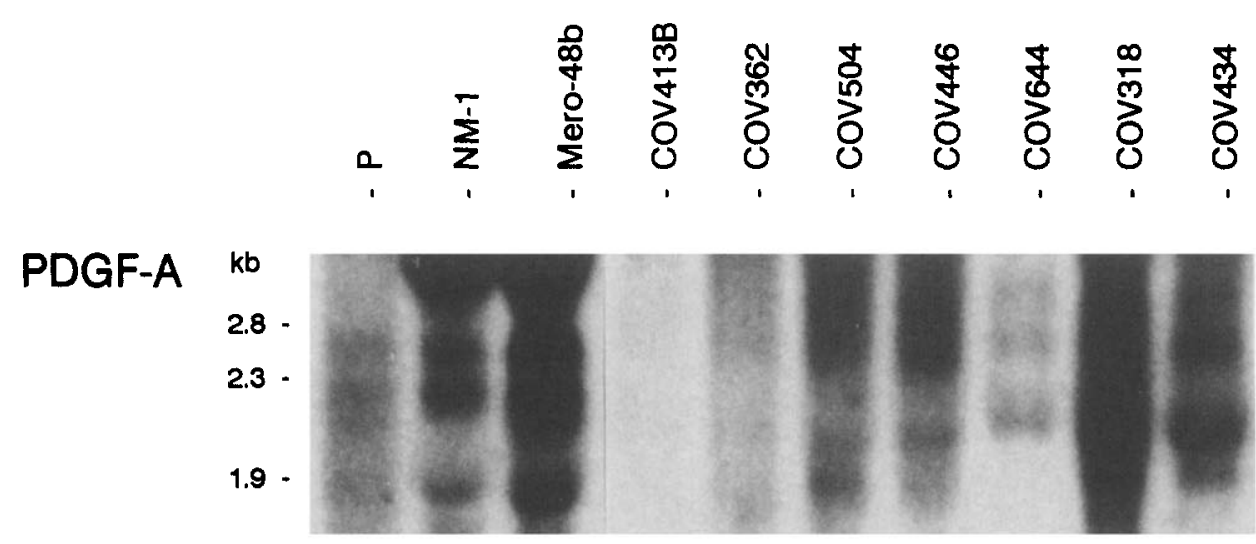

PDGF-B

GAPDH

1.2

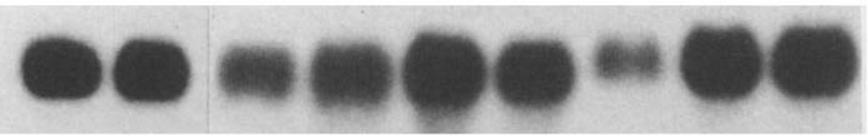

Figure 1. Northern blot analysis of $25 \mu \mathrm{g}$ total RNA from placenta (P), a normal mesothelial cell line (NM-1), a malignant mesothelioma cell line (Mero-48b), six ovarian epithelial tumor cell lines, and a granulosa tumor cell line (COV434). The filter was hybridized to ${ }^{32}$ P-labeled PDGF A-chain, PDGF B-chain, and GAPDH probe.

all the ovarian tumor cell lines of epithelial origin, whereas the granulosa tumor cell line COV434 showed no detectable PDGF B-chain transcripts (Fig. 1). The quality and amount of RNA applied were controlled by rehybridization with a glyceraldehyde-3-phosphate dehydrogenase (GAPDH) probe. In Table 1 the data of at least three separate experiments on PDGF chain and receptor expression are summarized.

Rehybridization of the same filters with probes for the PDGF $\alpha$ - and $\beta$-receptors revealed no specific transcripts for the PDGF receptors in the seven investigated ovarian tumor cell lines (data not shown). As described earlier, the normal mesothelial cells expressed predominantly the PDGF $\alpha$-receptor whereas the malignant mesothelioma cell line expressed only the PDGF $\beta$-receptor [10].

\section{Cytogenetic Aberrations Concerning Chromosome 22 and Southern Blot Analysis of the PDGF B-chain Gene in Ovarian Tumor Cell Lines}

The PDGF B-chain gene has been mapped to chromosome 22q13.1. To investigate the mechanism of PDGF B-chain expression we studied the ovarian tumor cell lines for chromosomal aberrations in chromosome 22 and DNA rearrangements in the PDGF B-chain gene. All six ovarian tumor cell lines from epithelial origin showed highly abnormal karyotypes with modal chromosome numbers ranging from 36 to 97. Findings concerning ploidy and chromosome 22 are given in Table 1 [11]. No constant structural abnormalities of chromosome 22 were observed. The number of copies of chromosome 22 compared to other autosomes did not correlate with the level of B-chain expression. Southern blot analysis of the ovarian tumor cell lines digested with various restriction enzymes revealed absence of DNA rearrangements in the PDGF B-chain gene and no amplification or loss of the PDGF B-chain gene (data not shown).

\section{Expression of PDGF and Its Receptors in Ovarian Tumor Tissue}

To investigate the PDGF chain and receptor expression on ovarian tumors in vivo, frozen tissue sections were stained. As a positive control the ovarian carcinoma marker OV632 [20] was used. All six ovarian tumors were positive for OV632. Slides stained with the second-step antibody only or with an irrelevant IgG1 antibody were negative. Using an antibody recognizing PDGF (AA, $A B$, and $B B$ ) expression of PDGF was detected in the tumor cells of all six investigated ovarian tumors (Table 2). Slides incubated with the PDGF antibody pretreated with PDGF-AA or -BB protein were completely negative (data not shown). The PDGF staining pattern of the tumor cells was characterized by a perinuclear staining (Fig. 2). As macrophages can also express PDGF, adjecent slides were also stained with the macrophage-specific antibody, CD68. CD68 was only observed in stromal cells while tumor cells were negative (data not shown). This observation indicates that the PDGF staining pattern was not due to reactivity with macrophages. No staining of tumor cells was observed with monoclonal antibodies recognizing the PDGF $\alpha$ - and $\beta$-receptors (Table 2). Occasionally, PDGF $\alpha$ - and $\beta$-receptor expression was detected in stromal cells. 
Table 2 Staining of frozen sections of ovarian tumors with antibodies against PDGF and its receptors

\begin{tabular}{|c|c|c|c|c|c|c|}
\hline \multirow[b]{2}{*}{ Patient } & \multirow[b]{2}{*}{ Diagnosis } & \multirow[b]{2}{*}{ OV632 } & \multirow[b]{2}{*}{ PDGF } & \multicolumn{3}{|c|}{ PDGF receptor } \\
\hline & & & & $\alpha$ & & $\beta$ \\
\hline $184-1$ & Papillary serous cystadenocarcinoma & \pm & + & $-b$ & & - \\
\hline $184-2$ & Serous cyst adenocarcinoma & $+a$ & + & - & & $-b$ \\
\hline $184-3$ & Papillary serous cystadenocarcinoma & + & + & \pm & - & - \\
\hline $184-4$ & $\begin{array}{l}\text { Undifferentiated papillary } \\
\text { adenocarcinoma }\end{array}$ & + & + & - & & - \\
\hline $184-10$ & Papillary serous adenocarcinoma & + & + & - & & - \\
\hline E $154-11$ & $\begin{array}{l}\text { Poorly differentiated papillary } \\
\text { serous cystadenocarcinoma }\end{array}$ & + & + & - & & - \\
\hline
\end{tabular}

\footnotetext{
a Heterogenous staining.

b Positive staining was observed in the stroma.

+ positive staining; \pm weakly positive staining; - negative staining.
}

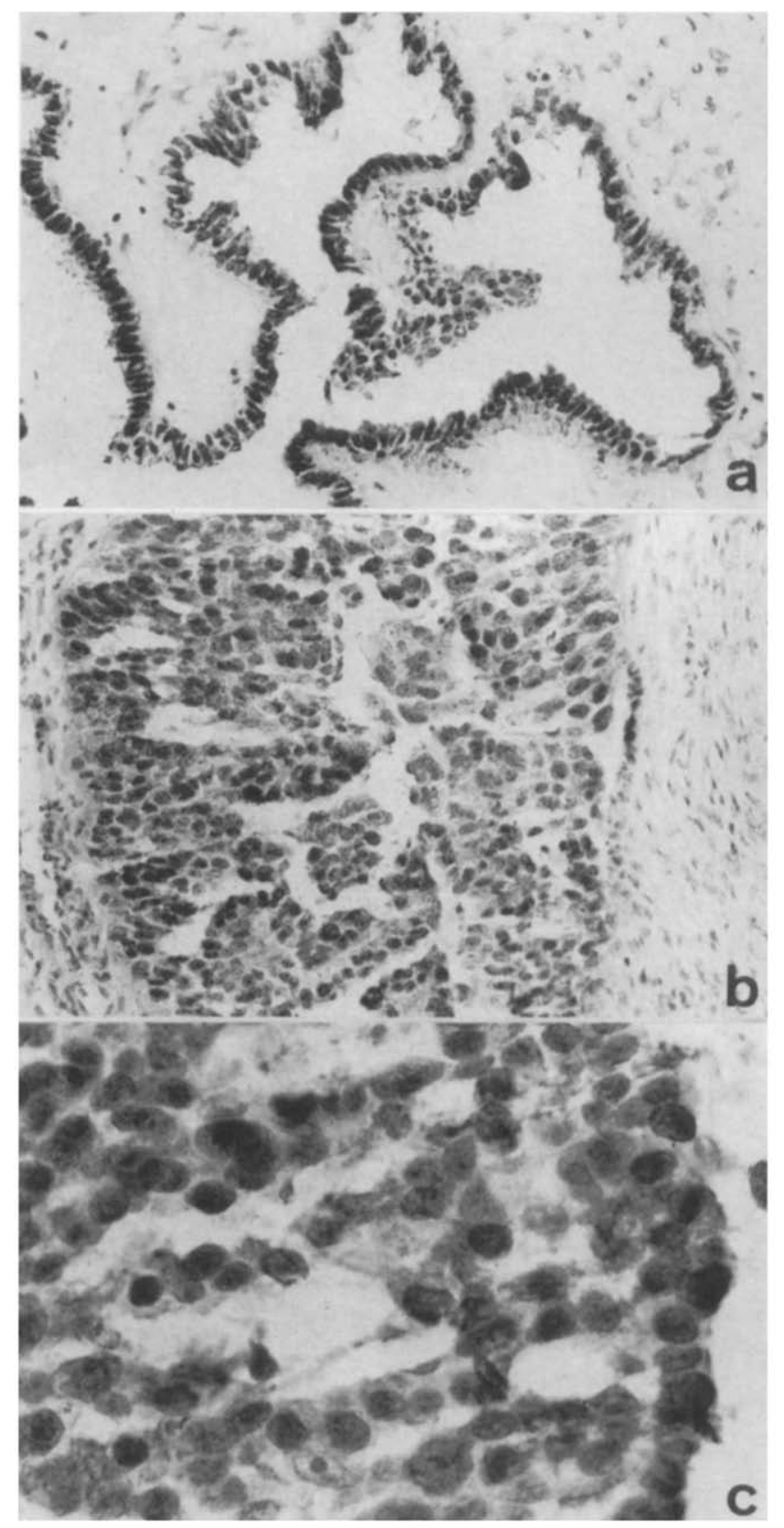

\section{DISCUSSION}

Earlier we described an elevated PDGF A- and B-chain expression in human malignant mesothelioma cell lines compared to normal mesothelial cells [9]. Epithelial ovarian tumors and melignant mesotheliomas are both considered to be of mesothelial origin. Comparison of ovarian epithelial tumor cell lines with malignant mesothelioma cell lines revealed that both types of tumor cell lines expressed the PDGF A- and B-chain genes. As primary ovarian surface epithelial cells cannot be cultured in adequate amounts we used pleural mesothelial cells and compared these with epithelial ovarian tumor cell lines. The epithelial ovarian tumor cell lines showed an elevated but variable PDGF B-chain expression compared to normal mesothelial cells, where this messenger was undetectable. Consistent with the data from the Northern blot analysis, expression of PDGF (AA, AB, and $B B$ ) was demonstrated in frozen sections of six serous ovarian carcinomas.

The earlier observed PDGF chain and receptor expression in malignant mesothelioma cell lines is suggestive of an autocrine growth stimulation $[9,10]$. A prerequisite for this stimulation is expression of the appropriate receptor. However, neither in the six epithelial ovarian tumor cell lines nor in frozen sections of ovarian tumors could $\alpha$ - or $\beta$-receptors be detected. These results indicate that the produced PDGF could only have a paracrine function. As PDGF is a chemoattractant and mitogen for endothelial cells and fibroblasts it can stimulate the formation of a supporting connective tissue stroma [21]. Recently it was demonstrated in an in vivo model that PDGF produced by tumor cells that lack PDGF receptors is a potent mediator of connective tissue stroma formation [22].

In conclusion, we have demonstrated expression of the PDGF A- and B-chain genes in six epithelial ovarian tumor cell lines, while a granulose tumor cell line was found to express the PDGF A-chain gene only. Furthermore, PDGF

Figure 2. Immunoperoxidase staining of frozen sections of ovarian carcinomas with monoclonal antibody PGFOof recognizing PDGF. Most tumor cells display an intense perinuclear staining. Papillary serous cystadenocarcinoma (patient 184-1) $\times 80$ (a) and a papillary serous adenocarcinoma (patient 184-10) showing a more heterogeneous staining $\times 80$ (b) and $\times 200$ (c). 
expression was demonstrated in frozen sections of six ovarian tumors. Expression of the PDGF $\alpha$ - or $\beta$-receptors was found in none of the investigated ovarian tumor cell lines or ovarian tumors. This study indicates that further investigation of PDGF expression in epithelial ovarian tumors might be of interest for the differential diagnosis between invasive and epithelial tumors, eliminating the group of borderline tumors.

We are grateful to Professor Dr. R. Benner for his continuous support and to Mrs. M.J. Bouts, Ms. E. Postma, Dr. S. Chadha-Ajwani, and Dr. M.E. Vierhout for their advice and technical assistance. Dr. L. Claesson-Welsh kindly provided the probes for the PDGF $\alpha$ - and B-receptor. Mr. T.M. van Os is acknowledged for excellent photographic assistance and Mr. H.J. Elsenbroek-de Jager for typing the manuscript.

Note added in proof: Recently Henriksen et al. (Cancer Res. 53, 4550-4554, 1993), demonstrated PDGF expression in 33 of 45 malignant ovarian tumors. PDGFa receptor expression, using a different antibody than in this study, was detected in 16 of 45 malignant tumors and correlated with a shorter survival.

\section{REFERENCES}

1. Roth LM, Czernobilsky B (1985): General aspects of the ovarian cancer. In: Tumors and Tumorlike Conditions of the Ovary, Roth LM, Czernobilsky B, eds. Churchill Livingstone, New York, Edinburgh, London and Melbourne, pp. 1-9.

2. Scully RE (1979): Tumors of the ovary and maldeveloped gonads. Atlas of tumor pathology, 2nd series, Fascicle 16. Armed Forces Institute of Pathology, Washington DC.

3. Sorbe B, Frankendal BO, Veress B (1982): Importance of histological grading in the prognosis of epithelial ovarian carcinoma. Obstet Gynecol 59:576-582.

4. Parmley TH, Woodruff JD (1974): The ovarian mesothelioma. Am J Obstet Gynecol 120:234-241.

5. Woodruff JD (1979): The pathogenesis of ovarian neoplasia. John Hopkins Med J 144:117-120.

6. Auersperg N, Siemens CH, Myrdal SE (1984): Human ovarian surface epithelium in primary culture. In Vitro 20:743-755.

7. Pepadaki L, Beilby JOW (1971): The fine structure of the surface epithelium of the human ovary. J Cell Sci 8:445-465.

8. Gerwin BI, Lochner JF, Reddel RR, Roberts AB, Robbins KC, Gabrielson EW, Harris CC (1987): Comparison of production of transforming growth factor-beta and platelet-derived growth factor by normal human mesothelial cells and mesothelioma cell lines. Cancer Res 47:6180-6184.

9. Versnel MA, Hagemeijer A, Bouts MJ, Van der Kwast ThH, Hoogsteden HC (1988): Expression of c-sis (PDGF B-chain) and PDGF A-chain genes in ten human malignant mesothelioma cell lines derived from primary and metastatic tumors. Oncogene 2: 601-605.
10. Versnel MA, Claesson-Welsh L, Hammacher A, Bouts MJ, Van der Kwast ThH, Eriksson A, Willemsen R, Weima SM, Hoogsteden HC, Hagemeijer A, Heldin C-H (1991): Human malignant mesothelioma cell lines express PDGF $\beta$-receptors whereas cultured normal mesothelial cells express predominantly PDGF a-receptors. Oncogene 6:2005-2011.

11. Van den Berg-Bakker AM, Hagemeijer A, Franken-Postma E, Smit VTHBM, Kuppen PJ, Comelisse CJ, Schrier PI (1993): Establishment and characterization of 7 ovarian carcinoma cell lines and one granulosa tumor cell line: growth features, immunophenotype and cytogenetics. Int J Cancer 53:1-8.

12. Versnel MA, Bouts MJ, Hoogsteden HC, Van der Kwast ThH, Delahaye M, Hagemeijer A (1989): Establishment of human malignant mesothelioma cell lines. Int J Cancer 44:256-260.

13. Betsholtz C, Johnsson A, Heldin C-H, Westermark B, Lind $P$, Urdea MS, Eddy R, Shows TB, Philpott K, Mellor AL, Knott J, Scott J (1986): cDNA sequence and chromosomal localization of human platelet-derived growth factor. A-chain and its expression in tumor cell lines. Nature 320:695-699.

14. Groffen J, Heisterkamp N, Stephenson JR, Geurts van Kessel A, de Klein A, Grosveld G (1983): c-sis is translocated from chromosome 22 to chromosome 9 in chronic myelocytic leukemia. J Exp Med 158:9-15.

15. Claesson-Welsh L, Eriksson A, Westermark B, Heldin C-H (1989): cDNA cloning and expression of the human A-type PDGF receptor establishes structural similarity to the B-type receptor. Proc Natl Acad Sci USA 86:4917-4921.

16. Claesson-Welsh L, Eriksson A, Morén A, Severinsson L, Ek B, Östman A, Betsholtz C, Heldin C-H (1988): cDNA cloning and expression of a human platelet-derived growth factor (PDGF) receptor specific for B-chain containing PDGF molecules. Mol Cell Biol 8:3476-3486.

17. Benham FJ, Hodgkinson S, Davies KE (1984): A glyceraldehyde3-phosphate dehydrogenase pseudogene on the short arm of the human X chromosomes defines a multigene family. EMBO J 3:2635-2640.

18. De Jong JP, Voerman JSA, Loenen PJM, Van der Sluijs-Gelling AJ, Ploemacher RE (1991): Improved fixation of frozen lymphohaemopoietic tissue sections with hexazotized Pararosaniline. Histochem J 23:392-401.

19. Shirashi T, Morimoto S, Itoh K, Sato H, Sugihara K, Onishi T, Ogihara $T$ (1989): Radioimmunoassay of human platelet-derived growth factor using monoclonal antibody towards a synthetic fragment of its B-chain. Clin Chim Acta 184:65-74.

20. Fleuren GJ, Coerkamp EG, Nap M, Van den Broek LJCM, Warnaar SO (1987): Immunohistological characterization of a monoclonal antibody (OV632) against epithelial ovarian carcinomas. Virchows Arch A 410:481-486.

21. Westermark B, Heldin C-H (1991): Platelet-derived growth factor in autocrine transformation. Cancer Res 51:5087-5092.

22. Forsberg K, Valyi-Nagy I, Heldin C-H, Herlyn M, Wostermark B (1993): Platelet-derived growth factor (PDGF) in oncogenesis: Development of a vascular connective tissue stroma in xenotransplanted human melanoma producing PDGF-BB. Proc Natl Acad Sci USA 90:393-397. 